\title{
Market Mechanisms for Reducing Emissions and the Introduction of a Flexible Consumption Tax
}

\author{
Agime Gerbeti $^{1}$ (D)
}

Received: 31 March 2021/Accepted: 20 July 2021/Published online: 14 August 2021

(C) Global Institute of Flexible Systems Management 2021

\begin{abstract}
Since its founding institutions the European Economic Community and Eratom, the European Union has paid great attention to energy issues. However, its powers have been updated in relatively recent times. Similarly, the EU has promoted in the post-Kyoto Protocol environmental issues with a leading by example approach and implementing an ambitious plan to decarbonize the economy with the energy transition and emission limitation through a market instrument, the emission trading system. The European emissions trading system has been the most ambitious management of negative externalities related to GHG set-up at the international level. The EU now considers that the costs of ecological industrial transition could limit the ability of European industries to compete in the globalized market with industries not subject to similar limits and costs. The EU intends to adopt a carbon adjustment tax at the border, to limit the phenomenon of reallocation and compensate for environmental costs. This paper analyses the various proposals and their advantages and disadvantages. The focus is on the charge on emissions mechanism, which is one of the three proposals the European Economic and Social Committee suggested to the European Commission for further investigation in view of the current competitive asymmetry now recognized by the EU Commission itself. The charge on emissions would value industrial emissions directly within the VAT and use the blockchain to track the emissive supply chain of products.
\end{abstract}

Agime Gerbeti

agime.gerbeti@gmail.com

1 LUMSA: Libera Universita Maria Santissima Assunta, Rome, Italy
Keywords Carbon border adjustment tax . Charge on emissions · Energy transition . Flexible environment protection . Industrial competitiveness

\section{Introduction}

Although the Treaty of Rome, establishing the European Economic Community (EEC) did not originally contain specific provisions on energy, this was present in the two institutions, from which this Community would have taken cue: in 1951 with the Coal and Steel Community ${ }^{1}$ and in 1957 with the European Atomic Energy Community. The first explicit reference (Scalia, 2020) to energy ${ }^{2}$ was introduced in the Maastricht Treaty $^{3}$ of the EEC. Since then, the growing needs of energy, environmental and industrial integration have led to a series of "climate-energy" packages. ${ }^{4}$ Previously, these issues were treated separately, for example, the directive 2001/77/EC on the promotion of electricity produced from renewable energy sources in the internal electricity market was not linked to

\footnotetext{
1 The ECSC Treaty lasting for 50 years from the date of its entry into force remained in force until 23 July 2002.

2 The Maastricht Treaty has included «measures in the field of energy, civil protection and tourism» (Art. 3, par. 1, lit. u).

3 Treaty on European Union, signed at that time by twelve members of the European Community on 7 February 1992, entered into force in 1993.

4 This package opened to an integrated energy and climate policy.
} 
the directive 2003/87/EC (the so-called ETS directive) (European Union, 2003) establishing a scheme for greenhouse gases (GHG) trading of permits, adopted by EU in implementation of the Kyoto Protocol (KP). ${ }^{5}$

Over the years, the cap \& trade mechanism for the enhancement of European industrial emissions has received widespread support from scientific literature such as Ellerman and Buchner (2007), Borghesi et al. (2016). Indeed, the EU ETS is deemed as an indispensable tool in the fight against climate change (Ellerman and Buchner 2007). While highlighting the importance of the EU ETS, Sijm et al. (2006) specify that it had a distortive result in respect to the industrial sectors that, while receiving the free allowances, could transfer this cost in the final price of products. This is especially true for Egenhofer (2007), where electricity producers operating in a domestic market transfer $\mathrm{CO}_{2}$ costs into the final electricity price.

In 2009, the first coordinated package, the so-called 20-20-20 was adopted. It laid the foundations for a Union governance of the energy transition. The package also included the revision of the ETS directive, i.e. Directive 2009/29/EC consolidating the ETS system as a key instrument (European Union, 2009a) of the Union for the emissions reduction of energy-intensive sectors. ${ }^{6}$ The revised directive set the target to reduce the Communitywide quantity of allowances for all EU plants by $21 \%$ within 2020 compared to 2005 levels. Furthermore, were introduced benchmarks per product (tonne product/tonne $\mathrm{CO}_{2}$ ) in individual industry sectors and free allowances allocations were justified to face the risk of carbon leakage. As Demailly and Quirion (2008) demonstrated in their study, the carbon leakage' issue was considered crucial for the third phase of the EU ETS. They argue that while the electricity sector has a leakage ratio equals zero, the other manufactural sectors are highly impacted. For instance, their study shows that the "aluminium sector in EU is trade sensitive and around $40 \%$ of its drop in production is due to trade, hence is offset by a rise in production abroad which is more $\mathrm{CO}_{2}$ intensive". Clò (2010) is also of this opinion, who argued that in order to deal with carbon leakage, free quotas would have continued to be central. Contrarily, Naegele and Zaklan (2019) think that there is no evidence

\footnotetext{
5 Then, with Directive 2004/101/EC, the European Union (EU) has recognized within the ETS the carbon credits generated from the flexible mechanisms of the KP (Clean Development Mechanism and Joint Implementation).

${ }^{6}$ Extending the scope for 2013-2020 by including other GHG, which bring inside the ETS such as aviation.
}

that the EU ETS, at least with low $\mathrm{CO}_{2}$ prices, has induced carbon leakage in European manufacturing sectors. In addition, Gilbertson and Reyes (2009) found that the EU ETS was "generously rewarded polluting companies while failing to reduce emissions". MacDonald and Cao (2014) added that, "the EU ETS had been on life support for years".

Structural limits of the system have emerged with the adoption of the market stability reserve mechanism (European Union, 2015) and through the progressive limitation of the quotas in the market, that occurred with the revision of the EU ETS directive (European Union, 2018) especially for the manufacturing industry (European Union, 2019). The increasing environmental and energy costs are limiting the competitiveness of even the most virtuous companies (European Union, 2014). From the EU institutions (European Union, 2019), it also emerges the requirement to find a synthesis between environmental and industrial needs (see Fig. 1).

In fact, the paradox is that precisely when the ETS, after years of difficulty in indicating an efficient price level, manages to indicate an adequate price (European Union, 2021), it risks widening the competitiveness gap between European and non-European companies: extra-European goods are also favoured on the Union market as they have much lower energy and environmental costs. Grubb and Neuhoff (2006) state that "profit and market share are not synonymous, and for internationally traded goods they are frequently in opposition: the more companies profit by raising the prices to reflect the opportunity costs of carbon, the greater the possible erosion of their market share over time".

Many subjects are supporting a carbon border tax at the European and US borders. Some proposals appear to be more quantitative and protectionist of national economies (Courchene \& Allan, 2008; McLure Jr, 2010; Hillman, 2013) rather than qualitative and selective on emissions reduction. The EU Council proposes to "apply only to countries without comparably stringent climate policies". According to the author's opinion, the measures proposed

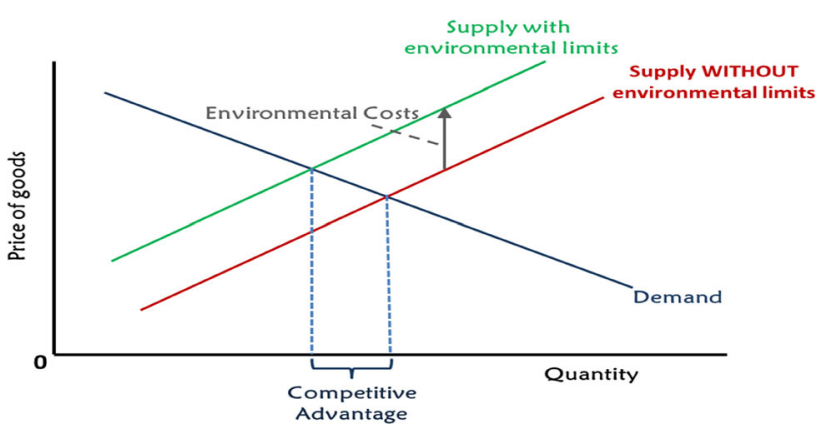

Fig. 1 Competitiveness gap 
this way will also be doomed to failure regarding environmental objectives. These approaches seem not able to overcome "the ancient" territorial design of legal systems and do not consider that the globalization and the fact that $\mathrm{CO}_{2}$ emissions do not respect borders. Gerbeti (2014) highlighted the competitive gap on a territorial basis and proposes the introduction of a charge on added emissions on goods.

The EU has listened to these needs and is trying to outline a carbon border adjustment tax which, in the intentions of the European legislator, should protect the European industry from environmental dumping. The draft measure has been submitted in July 2021.

The EU has almost completed the reform of energy and climate policy framework by translating into legislative acts the numerous proposals presented by the Commission within the Communication «Clean Energy for All Europeans». ${ }^{7}$ However, the 2030 objectives, in line with the Commission's commitments must be increased to achieve the goal of at least $55 \%$ emission reduction compared to 1990 level. ${ }^{8}$ To this end, a road map was introduced, within the New Green Deal ${ }^{9}$ strategy European Commission (2019). For the first time in an openly environmental policy, European industrial needs are taken into account. EU negotiations with member states are currently going on to align upwards the targets adopted before the introduction of the New Green Deal. On 6 March 2020, the EU and its member states submitted to the UNFCCC the "EU Longterm low GHG development strategy". ${ }^{10}$ That is fully in line with the EU Communication on the European Green Deal and endorsed the objective of achieving a climateneutral by 2050 .

\footnotetext{
7 The package with a target on emission reduction of $40 \%$ by 2030 consisted of several proposals: revision of five directives, revision of four regulations, three new regulations, two decisions, three communications and several preparatory and impact studies.

${ }^{8}$ For a comparative analysis between the levels of sustainability of the various EU countries, see Cucchiella et al. (2017).

9 The European Green Deal. Brussels, 11.12.2019. COM (2019) 640 final is included in the Communication from the Commission to the European Parliament, the European Council, the Council, the European Economic and Social Committee and the Committee of the Regions.

${ }^{10}$ Submission by Croatia and the European Commission on behalf of the European Union and its Member States Zagreb, 6 March 2020 Subject: Long-term low GHG development strategy of the European Union and its Member States. https://unfccc.int/sites/default/files/ resource/HR-03-06-2020\%20EU\%20Submission\%20on\%20Long\% 20 term\%20strategy.pdf
}

This work is intended to contribute to this debate by analysing whether a carbon border tax is an effective response for European industry and a useful environmental measure. The paper proposes to introduce a flexible market mechanism, the charge on added emissions (Gerbeti, 2014, 2016) which is expected to enhance negative externalities without discriminating products based on their national origin. A direct economic enhancement of the $\mathrm{CO}_{2}$ as a raw material emitted based on energy carrier used for the manufacture of products and on the overall emissions efficiency of the process. As written by Delbeke and Vis (2020) "the best carbon border adjustment mechanism may well be the one that is never used". Furthermore, Monjon and Quirion (2011) have shown that "if the border adjustment is based on best available technologies, more precisely on the recently defined EU product-specific benchmarks, then the adjustment would only be partial and carbon leakage would nevertheless be significantly reduced.

In 2020, the EU in order to repair economic and social damages caused by the coronavirus pandemic has approved the NextGenerationEU ${ }^{11}$ Fund. It has a budget of 806.9 billion euros. The core part of the NextGenerationEU is the Recovery and Resilience Facility — an instrument providing grants and loans to support reforms and investments in the EU Member States at a total value of EUR 723.8 billion. The hope is that this mechanism can be best exploited to make the EU post-COVID-19 12 greener, more digital, more resilient and more capable of addressing current and future challenges. To this end among the future EU resources to finance the NextGenerationEU are included also the future revenues deriving from the upcoming application of the carbon border adjustment mechanism (European Union, 2021).

Finally, this paper is organized as follows: Sect. 2 introduces the general overview through the literature review and policy provisions. Section 3 focuses on analysis of environmental legislation and discussion of the proposal of the carbon border adjustment mechanism. Section 4 illustrates the perspective of a flexible approach on facing climate change based on $\mathrm{CO}_{2}$ incorporated on goods. Finally, Sect. 5 shows the conclusions of the research.

\footnotetext{
$\overline{11}$ The EU's 2021-2027 long-term budget \& NextGenerationEU Facts and figures. Published: 2021-04-29 by Directorate-General for Budget (European Commission).

12 Ahmed et al. (2021).
} 


\section{General Framework}

\section{Outcomes and Corrective Measures of the European ETS}

The EU market mechanism ${ }^{13}$ aiming at containing $\mathrm{CO}_{2 \text { eq }}$ emissions, after years of attempts and adjustments (Fabbri, $2017)^{14}$ such as the market stability reserve (MSR) ${ }^{15}$ and back-loading, ${ }^{16}$ has reached a desired price per tonne of $\mathrm{CO}_{2 \mathrm{eq}}$ (Chuang et al., 2019). In fact, since 2007, European Commission (2003), ${ }^{17}$ the EU hopes were to reach a $\mathrm{CO}_{2 \mathrm{eq}}$ level price able to incentivize industries to invest in renewable energy and to carry out those restructuring of plants and production processes for increasing energy efficiency, i.e. to reduce energy consumption per unit of product and therefore reaching a lower emission intensity. ${ }^{18}$ However, this target has met many obstacles.

\footnotetext{
13 The EU ETS operates according to the limitation principle, which ensures that the available allowances have a value and can be traded. A ceiling is set on the total quantity of ETS GHG allowances that can be emitted by plants governed by this scheme: companies receive or buy emission allowances, which, if necessary, they can exchange. At the end of each year, companies must return enough allowances to cover their real emissions if they do not want to face fines. If a company reduces its emissions, it can keep unused allowances to cover future needs, or sell them to another company that is short of them. The exchange should create flexibility and ensure that emissions reductions occur when they are cheaper. The price of $\mathrm{CO}_{2}$ should encourage investments in clean and low-emission technologies.

14 The ETS has suffered macroeconomic factors such as the 2008 financial crisis and will be impacted by the economic consequences of the COVID-19 pandemic. See the Report from the Commission to the European Parliament and the Council on the functioning of the European carbon market. COM/2019/557 final/; see also Gerbeti (2010).

15 Decision (EU) 2015/1814 of the European Parliament and of the Council of 6 October 2015 concerning the establishment and operation of a market stability reserve for the Union GHG trading scheme and amending Directive 2003/87/EC.

${ }^{16}$ Commission Regulation (EU) No. 176/2014 of 25 February 2014 amending Regulation (EU) No. 1031/2010 in order to determine, in particular, the volumes of allowances to be auctioned in the period 2013-2020. Back loading is a "postponement" of the auctioning of quotas in phase III. This "postponement" of the volume put up for auction does not reduce the total number of allowances to be auctioned during phase III, but only changes their distribution over the period. The auction sales volume fell by 400 million allowances in 2014, 300 million in 2015 and 200 million in 2016.

17 Brussels, 24.12.2009 SEC (2009) 1710 final draft Commission staff working document impact assessment accompanying document to the Commission Decision determining a list of sectors and subsectors which are deemed to be exposed to a significant risk of carbon leakage pursuant to Article 10a (13) of Directive 2003/87/EC (2009)10251 final. Cit. The price used should be based on an average carbon price according to the Commission's Impact Assessment accompanying the Package of Implementation measures for the EU's objectives on climate change and renewable energy for 2020, which is interpreted as an allowance price of $30 € / \mathrm{tCO}_{2}$.
}

The EU ETS has already dealt with three regulatory periods and has entered the fourth phase. ${ }^{19}$ The first period (2005-2007) was a trial, and it is not worthy to highlight the limits. However, the volume of free $\mathrm{CO}_{2 \text { eq }}$ permits issued was excessive and the market price dropped to practically zero, because the excess of offer.

On the second phase, (2008-2012) expectations were much higher: the goal was to have a more correct and better-profiled allocation for industrial subjects with emission reduction obligations. During this phase, instead of the overallocation of permits, the industrial production decreased. This was due to the great subprime crisis (2006-2008),i.e. many industries went bankrupt, and others decide to reallocate production facilities to countries with cheap labour, lower taxes, and lower energy costs which would allow them for greater competitiveness in the final price of the product. Obviously, having a lower production, there was a lower demand for $\mathrm{CO}_{2 \mathrm{eq}}$ allowances. Therefore, with the fall in demand, the price dropped again to 3-4 $€ / t \mathrm{CO}_{2 \mathrm{eq}}$ instead of reaching $30 € / \mathrm{t} \mathrm{CO}_{2 \mathrm{eq}}$, which was considered by the European Commission as the "perfect" price to foster emission reductions. ${ }^{20}$ This price would have suggested to EU companies that they should carry out energy restructuring and energy efficiency measures, rather than buy allowances on the market to offset their industrial emissions. In the intentions of the European legislator, the allowance's price should have been slightly higher than the range of the cheapest industrial interventions such as renewable production or purchase more efficient machinery and the most expensive of such interventions as the geological sequestration of $\mathrm{CO}_{2 \mathrm{eq}}$ or the production of green or blue hydrogen.

For the third period (2013-2020), the EU Commission sought to improve the profile of industrial emissions. So, it was agreed the introduction of a linear reduction factor of $1.74 \%$ applying each year on the Union-wide cap, which would have led to $21 \%$ reduction in emissions at European level compared to 2005. Once again, the ETS was highly

\footnotetext{
18 The ETS IV emission reduction target is also being updated to align it with the new European targets for 2050 and the Paris Agreement. Cf. German Environment Agency, EU ETS up to 2030: Adjusting the Cap in light of the IPCC 1.5 C Special Report and the Paris Agreement, 07/2020, which concludes that the linear reduction factor must be increased also to save the effectiveness of the ETS. cit. pg. 26: "Our analysis shows that the main parameter of the EU ETS, the linear reduction factor (LRF) of its cap - set at $2.2 \%$ for the period 2021-2030-is substantially out of line".

19 On 27 February 2018, the Council formally approved the reform of the EU emissions trading system (ETS) for 2021-2030 phase.

${ }^{20}$ See Santibanez-Gonzalez (2017a, b). Installations for the capture of $\mathrm{CO}_{2}$, to pipelines for transport of $\mathrm{CO}_{2}$ or to $\mathrm{CO}_{2}$ storage sites, where he explores the relationship between establishing a pricing policy (tax) on carbon dioxide emissions to the atmosphere and the design of a supply chain network to capture and sequester carbon dioxide in geological reservoirs.
} 
impacted due to the low price of allowance unable to encourage productive efficiencies and use of renewable sources. $^{21}$ Therefore, it was decided the use of back-loading measure. This is to say, a withdraw from the market of a significant percentage of allowances hoping that those remaining would increase in price. Subsequently, the backloading mechanism became permanent calling it the market stability reserve (MSR). In addition, for the fourth ETS phase (2021-2030), the linear reduction factor value of the EU overall cap was increased at $2.2 \%$ per year.

The use of a market correction tool such as the MSR shows at least that the market is not self-sufficient and therefore requires continuous regulatory corrections. The question arises whether it would be more useful to impose directly an administered cost on $\mathrm{CO}_{2 \mathrm{eq}}$ emitted during electricity and industrial production, because this would at least enable entrepreneurs to calculate precisely the costs involved in budgetary planning. In any case, the economic recovery was too slow and the $\mathrm{CO}_{2 \text { eq }}$ price was not supported by the productive and industrial recovery.

One of the reasons for this fall in prices is the economic crisis, which has driven many European companies to reallocate production to non-EU territories as well as the obvious tendency of European consumers to buy imported goods at competitive prices, de facto delocalizing access to consumption.

By deciding ex ante the quantity of allowances to auction, it was assumed that European industry would have continued its production in a more or less predictable manner. In other words, if it is to be established beforehand how much pollution will be, it would be necessary to know in advance the economic and industrial development affected by the same environmental obligations that you want to predict.

Decision (EU) 2015/1814 on the MSR provides that the Commission analyses the impact of the MSR on growth, employment, industrial competitiveness in the Union and the risk of carbon leakage. By 2021 and every five years thereafter, the MSR will be reviewed in the light of the analysis of the smooth functioning of the European carbon market. Thefore will be regulated the percentage of allowances that flow into the reserve and the total number of allowances in circulation.

\section{Environmental Markets}

The environmental markets were formally demonstrated by Baumol and Oates (1971), theorized by (Brown, 2018; Tientenberg, 2010) inspired by the theory of R. Coase. They mainly concerned energy sector and are characterized by the creation of an "artificial" good in the form of a title,

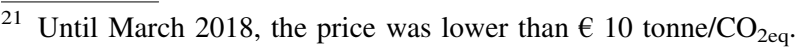

i.e. an asset that would not have received spontaneous economic value from the market if not supported by an obligation imposed on companies to create the relevant demand. The theoretical flexibility provided by this type of market is high. However, problems occurred during their actual implementation.

The problem is that, in the medium term, environmental markets seem to suffer from artificiality of the good exchanged. They were conceived with the idea of providing flexibility and therefore allowing the obliged entity the evaluation for greater cost efficiency between interventions in sustainability or buy on the market the corresponding certifications. Almost all environmental markets have been replaced by more typically administrative actions: green certificates (which were present in some countries including Italy, Poland, Romania, Denmark, the Netherlands, Sweden and the UK) have been almost entirely abandoned in favour of direct incentives on renewable energy production.

In a similar way, the ETS ${ }^{22}$ has been subject to such interventions on the side of the availability of allowances, functionally to the increase of $\mathrm{CO}_{2 \text { eq }}$ price. It is now difficult to recognize the free dynamics of demand and supply: the price appears to be controlled albeit with corrective market tools, such as the reserve and cancellation of allowances. In a perfect market, the meeting of supply and demand forms the cost of a good, which in turn is an expression of utility and marginal cost. In the $\mathrm{CO}_{2}$ market, therefore, a market structured on an artificial asset, the emission permits, the EU widening or restricting the audience of the obliged subjects alters the demand; in the same way, using the instruments of the MSR it manages, depending on the price responses, the offer on the market for emission permits. This external intervention by the EU is particularly evident in the trend of the cost on the allowances market (Fig. 2) and in fact, the price remained stable even during the COVID-19 pandemic.

The difficulties of these systems are due to a plurality of causes among which, the demand inelasticity in the short term, its little compatibility with the typical dynamics of the market and the tumultuous increase of the objectives. The first point highlights that the interventions that the obliged entities should implement in order to comply with the objectives, require multi-year investments.

The commitments in terms of purchase and management of emission allowances required by the constant and incremental demand of the ETS, in the short term, are an additional cost rather than a financial opportunity, unsustainable in many areas. However, the ETS market with obligations on industrial production takes the form of a rigid territorial vision, which is no longer adapted to the

\footnotetext{
${ }^{22}$ See footnote 13.
} 


\section{EUA}

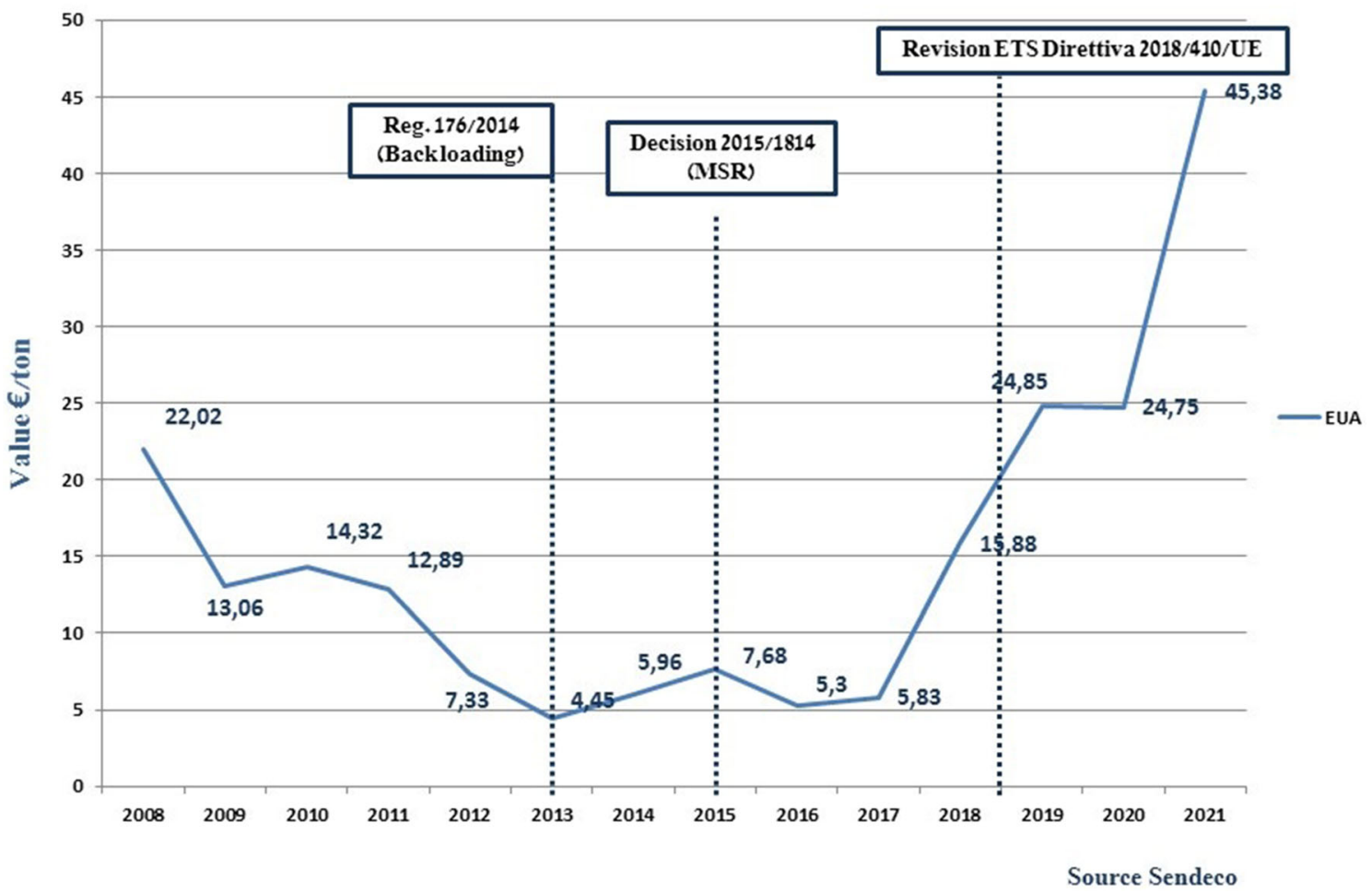

Fig. $2 \mathrm{CO}_{2}$ price $2008-2021$

world economic reality: European companies do not produce only for their citizens, but are confronted with a globalized world market. Similarly, non-EU industries that are not subject to environmental limits or included in the EU ETS obligations will produce also for European customers and export towards the EU without discounting any burden related to lower environmental and energy costs.

In a more concise term, the absence of similar impositions on all actors in the globalized market leads to competitive asymmetries between those who are subject to environmental objectives and competitors without such obligations: the higher the cost of allowances ${ }^{23}$ the wider the gap is in energy and environmental costs. The European manufacturer of ceramic, paper, steel, etc. that have already made investments in energy efficiency ${ }^{24}$ or will

${ }^{23}$ March 2021, 40, $57 €$. Source Sendeco.

${ }^{24}$ Cfr. Directorate-General for Climate Action (2015), Study on the Impacts on Low Carbon Actions and Investments of the Installations Falling under the EU Emissions Trading System (EU ETS), cit. pg. 179. "To what extent is EU ETS a driver for low carbon investment and operational decisions? How does the EU ETS influence decisionmaking? To what extent has this varied over the life of the EU ETS to date? What were the other drivers and what was the relative importance of the EU ETS in comparison to the other drivers? Based on our case studies and interviews, it becomes clear that carbon abatement and the carbon price were not the primary driving factors for most companies and sectors to invest in carbon efficient solutions. Instead, the main impetus came from the need for companies to have to buy allowances with increasingly high costs, will suffer in competition with similar Chinese, Indian and US products that did not face those costs, i.e. with higher final price of goods or the lower profit margin.

\section{Discussion}

\section{Proposals to Abate the Competitive Asymmetries}

In order to maintain the obligations of sustainability ${ }^{25}$ on European companies and at the same time address the lack of competitiveness of industries on energy and environmental costs with the similar extra-European producers, on

Footnote 24 continued

reduce energy and raw material costs and their broader strategic turn towards sustainable production, based on increasing environmental awareness of stakeholders and consumer markets".

${ }^{25}$ Negotiations have begun for the revision of the RED II Directive to align it with the European Green Deal. From the first results of the public consultation, it seems that a RES target will also be introduced for the industry. 
several occasions, ${ }^{26}$ it has been highlighted the need to set a price signal also on emissions not produced in Europe. This means putting a $\mathrm{CO}_{2 \text { eq }}$ price on emissions associated with extra-European production that compete on the domestic market with European productions. ${ }^{27}$ Even the President of the European Commission Ursula Von Der Leyen in the presentation of the "New Green Deal" package acknowledged the need to adopt a border tax generically referred to as a carbon border adjustment mechanism. $^{28}$

It is quite clear that, depending on the type of scheme adopted to implement the mechanism, the consequences for the domestic and import industries will change widely. If a scheme similar to the so-called French proposal of 2008 is adopted, the carbon inclusion mechanism, ${ }^{29}$ the obligation to purchase allowances will be imposed on the importer on the assumption that imported

\footnotetext{
${ }^{26}$ Lakshmi Mittal, chairman and chief executive of Arcellor Mittal, the world's largest steel producer, said that there is an urgent need to approve a tax on goods imported into Europe from countries that do not have a carbon price and that this is "the best answer on climate change". https://www.ft.com/content/8341b644-ef95-11e6-ba01119a44939bb6 12 February 2017. Thus, former American Secre taries of State, Baker and Shultz, and former Secretary of the Trea sury, Paulson, recently promoted an internal carbon tax and, of course, a border adjustment tax in the new administration. Interna tional New York Times of 09/02/2017.

27 See on this point Grubb and Neuhoff (2006) who state "Border tax adjustments, similarly, are unlikely to be 'all or nothing'. They would instead be considered in the context of particular industries and products, where a valid case for competitiveness concern was raised, and for which other solutions appeared inappropriate". Adding "Moreover, WTO law (and arguably EC State-aid law) may allow border tax adjustments that compensate for actual costs incurred, but not for opportunity costs". Cit. pp 35, 38.

${ }^{28}$ COM (2020) 102 final. Communication from the Commission to the European Parliament, the European Council, the Council, the European Economic and Social Committee and the Committee of the Regions. A New Industrial Strategy for Europe" Brussels, 10.3.2020, which states that, "Should differences in ambition around the world persist, the Commission will propose a Carbon Border Adjustment Mechanism in 2021 to reduce the risk of carbon leakage, in full compatibility with WTO rules. This should be supported by strengthening our current tools to tackle carbon leakage".

29 Ministère de l'écologie, de l'énergie, du développement durable et de l'aménagement du territoire, France. Preventing carbon leakage through a border adjustment mechanism Bruxelles-le 11 avril 2008. This proposal refers to Directive 2009/29/EC Article 10b “ By 30 June 2010, the Commission shall, in the light of the outcome of the international negotiations and the extent to which these lead to global greenhouse gas emission reductions, and after consulting with all relevant social partners, submit to the European Parliament and to the Council an analytical report assessing the situation with regard to energy-intensive sectors or subsectors that have been determined to be exposed to significant risks of carbon leakage. This shall be accompanied by any appropriate proposals, which may include: (b) inclusion in the Community scheme of importers of products which are produced by the sectors or subsectors determined in accordance with Article 10a".
}

goods have a level of emissions similar to the European average. ${ }^{30}$ Therefore, the importer will be forced to purchase only the difference between the European average emissions level and the EU benchmark indicated for that product. This mechanism has many conceptual gaps among which, one of the most evident is to assume that the average emissions of India and China are similar to the average of European emissions.

Otherwise, the carbon adjustment mechanism at the border could be structured as an entry custom duty on products based on the average emissions of the country of origin, or as a form more or less articulated as customs charge based on the country of import. In any case, the need represented by the industrialists, directly or indirectly, and welcomed by the EU institutions demonstrates the achievement of a series of awarenesses.

1. First of all, two categories of goods are competing on the European market: on one side, those subject to stringent environmental and energy legislation at the production stage and economically demanding: European ones, bound by emission targets, the energy costs of a certainly more sustainable European system (IEA, 2019) ${ }^{31}$ and with expensive energy efficiency targets; and on the other side those produced in countries without similar regulatory limits that enjoy lower energy $^{32}$ and environmental ${ }^{33}$ costs.

2. A second awareness lies in the fact that the cut in emissions covered by the European ETS is equal to approx. $0.4 \%$ of global emissions, therefore, not decisive. Especially because over the past 10 yearswith the exception of the economic crisis in 2009 and the global lockdown resulting from the pandemicglobal emissions have grown steadily by $2,5 \%$ per year, almost to demonstrate the marginality of $\mathrm{EU}$

\footnotetext{
30 From an environmental point of view, there would be no benefit in considering that emissions from products imported into the EU are included in the average emissions of EU products.

31 The world's largest oil consumers are China (3.1 Gtep), USA (2.3 Gtep) and India (0.929 Gtep); the largest coal consumers and producers are the same countries and are China produces $44.7 \%$ of the world total followed by India $9.7 \%$ and USA 9.2\%. Cfr. International Energy Agency (2019).

32 DG Trade (2014).

${ }^{33}$ COM (2019) 640 final. Communication from the Commission to the European Parliament, the European Council, the Council, the European Economic and Social Committee and the Committee of the Regions. The European Green Deal. Brussels, 11.12.2019: "As long as many international partners do not share the same ambition as the $\mathrm{EU}$, there is a risk of carbon leakage, either because production is transferred from the EU to other countries with lower ambition for emission reduction, or because EU products are replaced by more carbon-intensive imports. If this risk materializes, there will be no reduction in global emissions, and this will frustrate the efforts of the $\mathrm{EU}$ and its industries to meet the global climate objectives of the Paris Agreement".
} 
industry and its commitment to global warming. Thus, although the EU has reduced its overall emissions, ${ }^{34}$ this decrease is hardly attributable to the ETS (Gloaguen \& Alberola, 2013). ${ }^{35}$

However, the adoption of a carbon border adjustment tax could have one of the most serious consequences, that the European Commission considers a real and effective shield for the defence of companies subject to the risk of carbon leakage $^{36}$ or environmental dumping ${ }^{37}$ and, consistently, eliminate the free allowances ${ }^{38}$ that are currently allocated to these sectors with unpredictable effects on industry. ${ }^{39}$

Another possible consequence of the carbon border adjustment tax could be that the EU regulation can push prices up 60-70 €/allowance, to include even the most expensive technologies, creating a de facto unsustainable cost for European industry.

It is possible to make some considerations on the real environmental effectiveness of a carbon tax at the border. Assuming that Europe is able to impose a frontier tax, which takes into account the average emissions of the country of origin: the Chinese or Indian producer would have to pay an EU entry tax not equal to their real emissions, but the average of the emissions of the country in which the good is produced. Evidently, producers in order to have a reduced tax on import will not be able to significantly affect the country's energy supply mix, but inevitably, it will be subject to national energy policy choices.

\footnotetext{
${ }^{34}$ Intergovernmental Panel on Climate Change defines the carbon leakage as the increase in $\mathrm{CO}_{2}$ emissions outside countries that undertake a divided domestic mitigation action to reduce emissions from these countries" cit. Climate Change 2007: Mitigation; Contribution of Working Group III to the Fourth Assessment Report of the IPCC.

35 Assessing the factors behind $\mathrm{CO} 2$ emissions changes over the phases 1 and 2 of the EU ETS: an econometric analysis, Gloaguen and Alberola (2013).

${ }^{36} \mathrm{Cfr}$, https://ec.europa.eu/clima/policies/ets/allowances/leakage_en "Carbon leakage refers to the situation that may occur if, for reasons of costs related to climate policies, businesses were to transfer pro duction to other countries with laxer emission constraints. This could lead to an increase in their total emissions. The risk of carbon leakage may be higher in certain energy-intensive industries".

37 From the Treccani Encyclopaedia: "environmental dumping occurs when a company can place goods on the market at lower prices because they are produced at lower costs in countries where there is no legislation for environmental protection".

38 On the importance of free allowances for carbon leakage sectors see Clò (2011) and on the contrary (Joltreau \& Sommerfeld, 2019).

39 Cfr. European Green Deal (2019), "the Commission will propose a carbon border adjustment mechanism, for selected sectors, to reduce the risk of carbon leakage. It would be an alternative to the measures (such as the free allocation of emission allowances or compensation for the increase in electricity costs) that address the risk of carbon leakage in the EU's Emissions Trading System".
}

Europe would therefore place a carbon border adjustment linear tax on the emissions of industries, for example, Chinese, without allowing the individual producer to wriggle free from the national average. A non-EU industry faced with such limitations in exports to the European market would open an international dispute within the World Trade Organization (WTO) arguing that this tax is not based on actual emissions but on a prejudice that creates unjust damage so that this factory emits the same as the average of other national factories. ${ }^{40}$ Moreover, this industry, knowing that it would still pay the tax equal to the energy mix of its country, would seek to compensate for the increased taxation by paying less for raw materials, including energy less expensive ${ }^{41}$ and, therefore, more emissive energy mix. It would, in other words, be incentivized to emit more. In terms of energy costs, the low cost of coal would push the producer of goods to prefer this low-cost energy source for its plants, which would help saving and compensating the input tax on the foreign market.

In fact, a carbon tax at the border would have no environmental impact and would become a purely economic advantage based on higher state/European revenues in the form of higher border taxes. ${ }^{42}$ In addition, the EU seems to be missing ${ }^{43}$ further limits of a carbon tax on the border. First of all, the EU ETS is a tax on production but the carbon border tax will be set on import. This means that, even if this mechanism works, it could defend the competitiveness of European producers only on European territory. However, outside the borders EU industries would be outclassed by those companies not subject to

\footnotetext{
40 The difficult feasibility of applying a border tax, which does not give the importer the opportunity to demonstrate, is confirmed by the Court's judgment of 2 April 1998. Outokumpu Oy. Reference for a preliminary ruling: Uudenmaan lääninoikeus-Finland. Manufacturing tax on electricity-Tax rates differentiated according to the mode of production of electricity of national origin-Single rate for imported electricity. Case C-213/96. Indeed, it specifies that Finnish legislation "also does not give the possibility to the importer to demonstrate that the electricity imported by him was produced under certain conditions in order to benefit from the rate in force as the national electricity with the same modality".

${ }^{41}$ Finding economic convenience, maximizing profit and saving in raw materials that pays is intrinsic to entrepreneurial activity.

${ }^{42}$ All the $\mathrm{CO}_{2}$ adjustment mechanisms at the border require a fund to be set-up. It never happens that their use is reinvested $100 \%$ for the benefit of the environment. Not even the revenues of the $\mathrm{CO}_{2}$ auctions are totally dedicated to reducing emissions.

43 Despite the recent revision of the ETS system through the adoption of Directive 2018/410/EU, where while recognizing the problem of carbon leakage, it does not take the opportunity to truly address it. So until 2030, presumably we will continue with the free allocation and economic compensation "in favour of the sectors or subsectors exposed to a concrete risk of carbon leakage due to significant indirect costs actually incurred in relation to the costs of GHG transferred to electricity prices".
} 
environmental limits, which do not pay any tax or $\mathrm{CO}_{2 \mathrm{eq}}$ allowances or be affected by higher European energy and environmental costs entering the Union.

Then, if the EU were to impose a rise in emission costs at the levels indicated, the industry which, by producing in the EU, would pay on production (therefore before export) 60-70€/Tonne $\mathrm{CO}_{2 \text { eq }}$ would risk losing huge market shares as highlighted by the European Commission itself in the Communication "The European Green Deal". 44 This, also because the cost incurred by the European producer would be on the whole of production in Europe, whereas the cost paid by the carbon tax at the border by the non-European producer would only affect the quota that is exported to the EU, therefore only on a percentage of the production of that producer.

\section{Economic Limits of a Territorial Legislation}

A tax based on assumed average emissions of the country of origin would highlight a further lack of flexibility with respect to two macroeconomic phenomena that are characterizing the economy of this first twenty years of the twenty-first century: firstly in which country a certain good is actually manufactured and secondly for how long it will be produced in there? ${ }^{45}$

1. Trade implications-In the industrial field, emission limits structured on a national and territorial regulation become even more evident and inadequate in considering the change of world trade and production. In the current market, it does not matter where the factory is physically located, but the consumers' choices are based mainly by the quality of the good and the purchase cost. As effectively demonstrated by Sushil

\footnotetext{
44 Brussels, 11.12.2019 COM (2019) 640 final Communication from the Commission, The European Green Deal. "As long as many international partners do not share the same ambition as the EU, there is a risk of carbon leakage, either because production is transferred from the EU to other countries with lower ambition for emission reduction, or because EU products are replaced by more carbonintensive imports. If this risk materializes, there will be no reduction in global emissions, and this will frustrate the efforts of the EU and its industries to meet the global climate objectives of the Paris Agreement".

45 See the research of Rui Shan Oak Ridge National Laboratory, USA; Yaojin Sun, University of Tennessee, USA; and Sylvain Audette, HEC Montréal, Canada. Bitcoin mining to reduce the renewable curtailment: a case study of CAISO. 4th AIEE Energy Symposium. Current and Future Challenges to Energy Security. Conference Proceedings. 10-12 December, in Rome, Italy. Published 2019 by: The Italian Association of Energy Economists (AIEE), Rome, Italy, page 61, "Although these numbers are subjected to the change of machine price, electricity rate and regulatory issues, bitcoin price and the hash rate, they can qualitatively tell that by combining Bitcoin mining and renewable curtailment, we can mitigate the environmental concerns and generate economic benefits".
}

(2015), in order to maintain their competitiveness, industries need to adapt to the demands of consumers or the legislation of the host market. For example, all non-EU industries that intend to sell cars in the important EU market will have to produce in accordance with the regulatory standards of European emissions. Therefore, adaptation and flexibility (Sushil, 2011; Evans \& Bahrami, 2020) in the production process are not only instruments of competitiveness but are essential industrial needs (Shukla et al., 2019).

Some argue (OECD, 2010; Wojciech, 2019) that globalization represents a more effective allocation of resources. It is perhaps closer to the truth, that the competition of labour costs, energy costs, taxation and environmental simplifications leads the production system towards a more economically efficient use of resources.

In the globalized market, companies can choose where to pay taxes and which market to target: globalization has created a sort of industrial nomadism. ${ }^{46}$ Today, Fiat ${ }^{47}$ is no longer in Turin: it is somewhere else between Canada, Italy, the USA and the Netherlands; Amazon acts worldwide but is a company incorporated under US law and in Europe pays taxes in Luxembourg ${ }^{48}$; Apple, one of the leading US technology manufacturers, produces in China and has no physical stores, apart from a few representative boutiques. Nevertheless, you could indefinitely continue. For example, companies operating in the production of energy move between countries according to the incentives recognized for renewables. If the US puts tariffs on Chinese products, companies like Nike, Samsung and LG go to produce in Vietnam ${ }^{49}$ by growing its GDP in 2019 to more than $7 \% .^{50}$

In this context, imposing an emissive limit on goods produced by an industry based on its country of origin seems anachronistic. The industry would choose where to locate production depending on the convenience of energy supply and resources. It would probably choose the non-EU nation that is recognized by EU as a low emission country. Just as it is happening now. Countries are competing to offer tax havens to large companies. With the

\footnotetext{
46 Gerbeti (2019).

47 Acronym of Fabbrica Italiana Automobili Torino.

${ }^{48}$ https://www.theguardian.com/technology/2018/apr/25/from-seattleto-luxembourg-how-tax-schemes-shaped-amazon.

49 https://www.corriere.it/economia/finanza/19_giugno_16/vietnamcrescita-record-yacht-perche-nuova-frontiera-super-ricchi-7b3f80e082e9-11e9-9233-14aa8d8cebf9.shtml.

${ }^{50}$ Source Hanoi General Office of Statistics (2020).
} 
introduction of a linear carbon border adjustment tax, they would be competing to offer the best conditions of access to the European market.

2. Flexibility-The flexibility on the recognition of environmental impacts can never be an approximation such as a linear tax that equalises different companies that operate on the same territory. In addition, a genuinely flexible approach should not fail to take into account the fact that, beyond the artificial market of the $\mathrm{CO}_{2 \text { eq }}$ price in the EU ETS there is also a market for goods and services and that this market is globalized.

A flexible approach is a tailor-made approach, taking into account the real and timely differences in environmental impacts.

(a) On one side, quantify (from a fiscal point of view) a cost per tonne of carbon that is adequate to the environmental cost and, therefore, convenient for the producer to invest in making his plants more efficient and in the renewables;

(b) On the other side, it must rebalance the added fiscal revenue related to high-carbon products, reducing at the same time the taxation for lowcarbon products and avoiding the dreaded inflation: therefore a tax-neutral mechanism.

(c) Finally, there must exist a linear and not discriminatory methodology to quantify the right amount of $\mathrm{CO}_{2} \mathrm{eq}$; it is therefore necessary to create advantages on a worldwide scale for those who produce in a more efficient way in order to export products to Europe without being subjected to a higher taxation.

\section{Flexibility in calculating emissions: Charge on added emissions ${ }^{51}$}

As mentioned above, it can be said with good approximation that the energy costs of an industrial production are inversely proportional to the emissions level of the energy supply mix. It is precisely on this unavoidable assumption that the EU is seeking, through the application of a carbon border tax, to compensate for the increased environmental

\footnotetext{
$\overline{51}$ Charge on Emissions (Imposta sulle Emissioni Aggiunte) based on the book " $\mathrm{CO}_{2}$ nei beni e competitività industriale europea" (2014) was object of a resolution of the joined Commissions X and XIII, approved at the conclusion of the examination of the deal assigned on competitive asymmetries for European industry deriving from the low energy costs and low environmental standards in nonEU Countries, 1 August 2017. Doc. XXIV, n. 79 of the Italian Senate's Joint Commissions Productive Activities and Environment.
}

costs and competitive asymmetries ${ }^{52}$ created in the European market.

In the purchase of the cheapest product that is usually more emissive, the externality of production translates into externality of consumption. Buying a good from a country not subject to environmental limits and produced with an inefficient industrial chain creates a negative externality to consumption as an expression of higher emissions. Therefore, the key point can only be the consumption, towards which any production tends. So, consumption externalities need to be treated properly.

A viable way is to recognize the externality pollution as if it were an accessory to the product purchased, as if it were physically contained in goods: 1 tonne $\mathrm{CO}_{2 \mathrm{eq}}$ cost is equivalent to the cost incurred, under similar competitive conditions, to avoid the emission of that tonne of $\mathrm{CO}_{2 \mathrm{eq}}$.

Europe can set limits on GHG emissions on industrial production outside Europe if it considers them not an input for the energy used for production, but as a real output, as a by-product associated with the manufactured product, as if the shoe or pan contained it. Precisely, as if the $\mathrm{CO}_{2 \mathrm{eq}}$ produced during the manufacturing process of the good became an intrinsic characteristic of that good, a product incorporated in it. ${ }^{53}$

Recognizing $\mathrm{CO}_{2 \mathrm{eq}}$ as an externality of consumption, with a certain cost established administratively, ${ }^{54}$ would eliminate the competitive asymmetries between goods produced with different rules, but sold in the same European market. This, because costs on products containing the $\mathrm{CO}_{2 \mathrm{eq}}$, would be recognized both on European goods and on those manufactured in China, Mexico, India or wherever the manufacturer decided to move the factory.

\footnotetext{
52 Cfr. United Nations Environment Programme and the World Trade Organization (2009) in Trade and Climate Change, says "the carbon constraint in future emission trading schemes (for example, in Phase III of the EU-ETS) is expected to be more stringent, with a lower capped limit and fewer free allowances. This may therefore increase the potential impact of carbon costs on the competitiveness of a number of industrial sectors". Cit. pg. 21.

53 The General Agreement on Tariffs and Trade (GATT 1947), Part I, Article II: Schedules of Concessions, $2^{\circ}$ par: "Nothing in this Article shall prevent any contracting party from imposing at any time on the importation of any product: (a) a charge equivalent to an internal tax imposed consistently with the provisions of paragraph 2 of Article III* in respect of the like domestic product or in respect of an article from which the imported product has been manufactured or produced in whole or in part;".

${ }^{54}$ Environmental protection has historically been directed, in the context of administrative law, towards two major strands, on the one hand the imposition of limits and obligations, on the other an environmental protection through the market with the creation of artificial markets (green, white, ETS certificates). In the book "A Symphony for energy" 2015, Editoriale Delfino is represented a "third way" (cit. Staffetta Quotidiana) compared to the two classic strands, which enhances $\mathrm{CO}_{2}$ in the production process and follows its paths in international trade.
} 
Therefore, in a context of competitive asymmetry, ${ }^{55}$ a correct optimization of the $\mathrm{CO}_{2 \mathrm{eq}}$ associated with products should enhanced by public action leaving private enterprises and consumer demand to find the optimum balance.

The Charge on Added Emissions was introduced in the book " $\mathrm{CO}_{2}$ nei beni e competitività industriale europea" $\left(\mathrm{CO}_{2}\right.$ in goods and the European industrial competitiveness) is one of the proposals for the reform of the European emissions trading scheme. It is part of the broad genus of the "carbon tax" by economically enhancing the value of emissions released during the manufacturing processes of the products and proposes an equalization of this value in percentage form on the VAT of the individual goods, with the aim to make the less emissive products more competitive on the final consumer price.

Indeed, if you want to give a value to the consumption of $\mathrm{CO}_{2 \text { eq }}$, as an externality, the value-added tax (VAT) would be the ideal ${ }^{57}$ channel to act. It is flexible, easily traceable and imposed on the product when the good enter the market without this falling under the general prohibition of unfavourable conditions imposed by the WTO. The most suitable solution is to use the VAT as a clearing house while applying a lower value to "clean" products and a higher one to "polluting" products. So, adjusting the VAT based on the carbon intensity of products (see Fig. 3).

Certainly, not all EU countries ${ }^{58}$ have the same tax on consumption and that many territories, often detached, do not have it. It is also very likely that a policy that leads to greater uniformity of taxation in the EU passes through the

\footnotetext{
55 Opinion of the European Economic and Social Committee on 'The sectoral industrial perspective on reconciling climate and energy policies' (own-initiative opinion) (2019/C 353/10). Official Journal of the European Union, 18.10.2019, considers the Charge on Emissions one of alternatives to solve the unfair competitiveness issue contemporanei to reduce emissions.

56 Gerbeti (2014).

57 VAT was the first tax to be broadly harmonized at EU level, so back in 1970 it was logical to introduce a VAT-based EU budget own resource as a source of revenue alongside customs duties on imports and agricultural levies. https://ec.europa.eu/info/strategy/eu-budget/ long-term-eu-budget/2021-2027/revenue/own-resources/value-addedtax_en.

58 For tax arrangements applicable to intra-Community supplies and exports of goods, in Italy is in force Decreto-legge del 30 agosto 1993 n. 331 on harmonization of provisions relating to taxes on mineral oils, alcohol, alcoholic beverages, manufactured tobacco and VAT with those laid down in EEC Directives and consequent amendments thereto, as well as provisions on the regulation of approved tax assistance centres, procedures for tax refunds, the exclusion from ILOR of entrepreneurial income up to the amount corresponding to the direct employment contribution, the introduction of an extraordinary tax on certain assets and other tax provisions for 1993. Article 41, paragraph 1 "Intra-Community non-taxable supplies" provides the details for the territoriality for VAT. For supplies, the taxation regime in the EU State of destination of the goods subject to the transaction shall apply.
}

Charge on added emissions

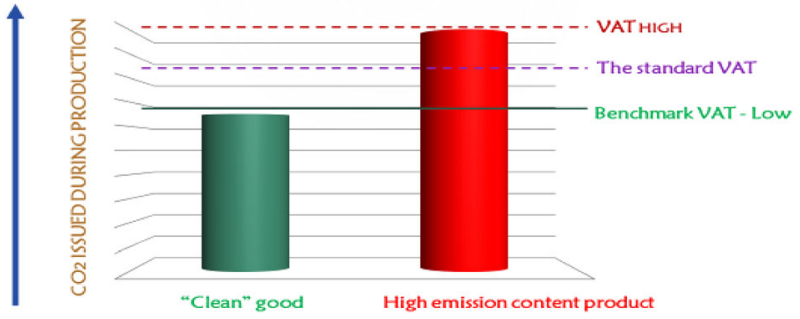

Fig. 3 Charge on added emissions mechanism

environmental protection. ${ }^{59}$ Already in the Multiannual financial framework (2021-2027) and Next Generation EU Fund $^{60}$ we notice the first signs of greater European fiscal integration, for example, revenues deriving from the constituent carbon tax at the border have already been budgeted. Picek (2020), who conducted an analysis of the economic effects of the reconstruction plan Next Generation EU, highlights the need for a coordinated fiscal policy response to the economic consequences of the coronavirus pandemic to optimize the effectiveness of measures to stimulate the economy. These represent the first cries of a European financial collection and its redistribution.

Such mechanism does not discriminate between EU and international goods as the charge on added emissions is based on the specific emissions of the product. Therefore, any company that produces goods in accordance with the set standards will not be subject to the additional charge within the VAT. It will be rewarded with a lower VAT, if it is more virtuous compared to the EU standard.

However, two aspects must be underlined:

1. The first is that production processes and the energy mix have nothing to do with the long debated problem

\footnotetext{
59 The plastic own resource, in place since 1 January 2021, consists of a national contribution based on the amount of non-recycled plastic packaging waste. This own resource is closely linked to the EU policy priorities. This is expected to encourage Member States to reduce packaging waste and stimulate Europe's transition towards a circular economy by implementing the European Plastics Strategy. At the same time, it leaves Member States the possibility to define the most suitable policies to reduce plastic packaging waste pollution in line with the principle of subsidiarity. A uniform call rate of $€ 0.80$ per kilogram will be applied to the weight of plastic packaging waste that is not recycled, with a mechanism to avoid excessive contributions from less wealthy Member States. https://ec.europa.eu/info/strategy/ eu-budget/long-term-eu-budget/2021-2027/revenue/own-resources/ plastic-own-resource_en.

${ }^{60} \mathrm{https}$ ///ec.europa.eu/info/strategy/eu-budget/long-term-eu-budget/ 2021-2027/revenue/potential-new-sources-revenue_en. Since 2018, the Commission has proposed several solutions for new sources of revenue of the EU budget. A new contribution based on the nonrecycled plastic packaging waste has now been introduced. Work towards the introduction of sources of revenue linked to a carbon border adjustment mechanism, a digital levy and the EU Emission Trading System (EU ETS) continues.
} 
concerning "made in". We are not talking about deciding if a type of product must or must not have a label reporting whether it's been produced in Germany or Italy the problem is evaluating the exact amount of $\mathrm{CO} 2$ that were emitted in order to produce or dispose of it.

2. The second aspect is that such a charge is not an import tax but a way to urge enterprises to optimize efficiency, regardless of where they operate. It does not deal with borders but with $\mathrm{CO} 2$, which should be clearly labelled on every product.

As seen, the charge on added emissions (Gerbeti, 2014) is a mechanism for the equalization of environmental costs on products traded on the European market. At the same time, it creates a standard and a stimulus because it does not target single States as seen in the Conference of the Parties of the UNFCCC are strongly reluctant to adopt restrictive and internationally valid environmental rules. In fact, in the Paris agreement, there are no sanctions. The proposal addresses directly industries that must feel the need to decarbonize as an advantage in the market. This mechanism proposes a parameter of industrial competition for environmental protection and is deemed to be in line with the WTO rules. ${ }^{61}$ This approach would create the same level playing field for EU products in competition with those of emerging countries, at least from the environmental and energy point of view. In addition, the public perception of paying $\mathrm{CO}_{2 \text { eq }}$ on purchased goods would raise awareness on these issues. ${ }^{62}$

\section{Counting and Traceability of Emissions in the World Production Chain}

The control of private information and the monitoring of habits, lifestyles and even digital consumer relations is at the heart of concerns of democratic countries. The world seems to be small and without privacy for those who produce and sell goods and for those companies that intend to profile consumers. Often the definition of consumer overlaps with that of citizen, and both figures are profiled in dozens of commercial statistics, political, and social and followed, tracked and monitored.

It seems paradoxical that private companies have personal information of citizens and that national institutions do not know exactly the Chinese energy mix or do not have

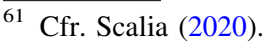

62 The expectation is to have a shift from $\mathrm{CO} 2$ intensive product to other less harmful for the environment. The awareness campaign towards consumers is intrinsic to the proposed mechanism. This because the evidence of having two equal products with VAT differentiated according to the content of $\mathrm{CO}_{2}$ intends to direct precisely the choices of the consumer towards the most sustainable product.
}

statistics on the efficiency of Vietnamese industries. It is also paradoxical that the EU, which has been the key actor for environmental commitments and that makes its companies and citizens pay for this leadership, is not in a position to know how much $\mathrm{CO}_{2 \mathrm{eq}}$ has been emitted for the production of one tonne of steel in Burma, or in India, or how much invasive the fracking techniques or shale gas extraction are. There are internationally recognized both emission standards and technologies to trace emissions of goods in every part of the planet, from raw materials to waste treatment. The world must not be transparent only for those who produce but also for those who trace, monitor, welcome these goods in the market. It is possible to recognize the $\mathrm{CO}_{2 \text { eq }}$ emitted during the production of a specific good or material as a feature of that good or material. The emission profiling or in general the environmental impact of a good dates back to the ' 70 s with the so-called life cycle assessment. ${ }^{63}$ This process evaluates the environmental performance of a product [...] on a global basis and its possible improvements estimated in total terms, i.e. from cradle to grave. ${ }^{64}$

Actually, the LCA is a kind of analysis that "wants to prove too much" with a significant risk of double counting. Nevertheless, the emission profiling of goods is a methodology that already now characterizes the European internal system for the calculation of emissions, in fact in Directive 2009/29/EC European Union (2009b) together with the concept of carbon leakage (art. 10a par. 15, 16 ${ }^{65}$ )

\footnotetext{
${ }^{63}$ From Wikipedia: Life-cycle assessment or LCA (also known as life-cycle analysis) is a methodology for assessing environmental impacts associated with all the stages of the life-cycle of a commercial product, process, or service. For instance, in the case of a manufactured product, environmental impacts are assessed from raw material extraction and processing (cradle), through the product's manufacture, distribution and use, to the recycling or final disposal of the materials composing it (grave). Widely recognized procedures for conducting LCAs are included in the 14,000 series of environmental management standards of the International Organization for Standardization (ISO), in particular, in ISO 14,040 and ISO 14,044.

${ }^{64}$ Treccani, Volume III. Nuovi Sviluppi: Energia, Trasporti, Sostenibilità, cap. 7. Confronto tra sistemi energetici. http://www.treccani.it/ export/sites/default/Portale/sito/altre_aree/Tecnologia_e_Scienze_ applicate/enciclopedia/italiano_vol_2/631-650_ita.pdf.

${ }^{65}$ Cfr. Directive 2009/29/CE art 10 a. par. 15. sector or subsector shall be deemed to be exposed to a significant risk of carbon leakage if: (a) the sum of direct and indirect additional costs induced by the implementation of this Directive would lead to a substantial increase of production costs, calculated as a proportion of the gross value added, of at least 5\%; and (b) the intensity of trade with third countries, defined as the ratio between the total value of exports to third countries plus the value of imports from third countries and the total market size for the Community (annual turnover plus total imports from third countries), is above 10\%". And in par 16. "Notwithstanding paragraph 15 , a sector or subsector is also deemed to be exposed to a significant risk of carbon leakage if: one of values a and $\mathrm{b}$ of par. 15 is, respectively, at least $30 \%$ or above $30 \%$. With the dir. 2018/410/UE the concept of carbon leakage is in article $10^{\circ}$ par.1.
} 
European Commission (2011) and European Union (2018) was introduced for the first time also the concept of benchmark (art. 10a par. $2^{66}$ ). This parameter is defined as $\mathrm{tCO}_{2 \mathrm{eq}} / \mathrm{t}$ of product. The established values are very strict and precise because are defined on the arithmetic average of the performance of the 10 best European plants.

It could be argued that it is different to follow the $\mathrm{CO}_{2 \mathrm{eq}}$ contained in the various goods through countless industrial and commercial steps from the factory of soles in China to that of uppers in Thailand or Australia to get assembly in Florence. As already mentioned, emissions profiling already takes place at European level. This is done functionally at the level of the allowances to be allocated and the obligations to be fulfilled with regard to the EU ETS. Indeed, the scheme foresees, through the benchmarks, that the calculation of emissions is carried out per unit of product so, the amount of emissions for that certain good is attributed. However, if we prefer not to use European instruments, at international level, there is already a technical rule on emissions, which is ISO 14064. In any case, the creation of an ad hoc process structured on a lightened version of the life cycle assessment does not seem insurmountable. The traceability of emissions involves the traceability of the transactions of $\mathrm{CO}_{2 \mathrm{eq}}$ in the productive processes from the extraction, passing for the refining and the fabrication of the materials to the production of the good.

There is a technological solution to certify this process, and it is called blockchain technology in which traceability

\footnotetext{
Footnote 65 continued

"Sectors and subsectors in relation to which the product resulting from multiplying their intensity of trade with third countries, defined as the ratio between the total value of exports to third countries plus the value of imports from third countries and the total market size for the European Economic Area (annual turnover plus total imports from third countries), by their emission intensity, measured in $\mathrm{kgCO}_{2}$, divided by their gross value added (in euros), exceeds 0,2 , shall be deemed to be at risk of carbon leakage. Such sectors and subsectors shall be allocated allowances free of charge for the period until 2030 at $100 \%$ of the quantity determined pursuant to Article $10 \mathrm{a}$ ".

${ }^{66}$ Cfr Directive 2009/29/CE, article 10a "Transitional Communitywide rules for harmonized free allocation" par. 2. In defining the principles for setting ex-ante benchmarks in individual sectors or subsectors, the starting point shall be the average performance of the $10 \%$ most efficient installations in a sector or subsector in the Community in the years 2007-2008. The Commission shall consult the relevant stakeholders, including the sectors and subsectors concerned. Cfr. the revision from dir. 2018/410/UE (2021-2030) par. 2. "For the period from 2021 to 2025 , the benchmark values shall be determined on the basis of information submitted pursuant to Article 11 for the years 2016 and 2017. On the basis of a comparison of those benchmark values with the benchmark values contained in Commission Decision 2011/278/EU (European Commission 2011) as adopted on 27 April 2011, the Commission shall determine the annual reduction rate for each benchmark, and shall apply it to the benchmark values applicable in the period from 2013 to 2020 in respect of each year between 2008 and 2023 to determine the benchmark values for the period from 2021 to 2025 ".
}

becomes an automatic process for participants in the system without risks of double counting and with a completeness of information never reached before (Gerbeti \& Catino, 2019).

With the blockchain, the problem finds a specific solution: compared to the physical world in which $\mathrm{CO}_{2}$ emission (Khaqqi et al., 2018) is identical to another good of equal magnitude. In the digital world, it is possible to identify in an unequivocal way a certain emissive transition by giving it features, information that tell the story of that specific emission of $\mathrm{CO}_{2 \mathrm{eq}}$ (from who was produced, to who was transferred, etc.). In other words, in the real world, it is customary to define some goods as fungible, that is, goods, such as currency or electricity (Favoro, 2019), without a specific individuality and therefore liable to substitution and exchange. It is not about that specific currency it is about the equivalent. In the digital world, however, it is possible to recognize that specific currency, that specific transaction. This information is transparent and recognized by the entire blockchain network so that a certain company will not be able to use its sustainability credit for a transaction other than the one for which it was generated.

Returning to the $\mathrm{CO}_{2}$ allowances the problem of quantifying the $\mathrm{CO}_{2 \mathrm{eq}}$ that characterizes a single product cannot be seem as unsolvable: this result becomes a mathematical and automated consequence of the production process. A bit like putting a barcode on the sole that will be used to produce a shoe. That sole carries with it emissions produced by the processing of crude oil, in the case of synthetic rubber or from livestock in the case of leather and whoever buys it will know the specific level of $\mathrm{CO}_{2 \mathrm{eq}}$. Each of these barcodes or emissive signatures constitute $\mathrm{CO}_{2 \mathrm{eq}}$ transactions that are certified by all the nodes of the blockchain network involved in a certain, immutable and transparent way. Each emissive transaction is noted in each node participating in the network, which, therefore, in the absence of conflicts or inconsistencies approves the transaction.

In the industrial chain (Fu et al., 2018), the user of a specific asset, whether it is a subsequent producer of the industrial chain or the final consumer, will be able to choose the good that seems most convenient to him. This also functionally on emissions that characterize it, based on the valorization that has been made of the $\mathrm{CO}_{2 \mathrm{eq}}$ contained in that good. In fact, with the assembly of the sole and upper, including their emissive history, a shoe will be produced with a new emissive footprint but with the memory of previous steps. In other words, the shoe manufacturer may be interested in choosing the sole manufacturer that is less emissive in its production because this will lead to a greater sustainability of its final product, namely the shoe. For example, the frozen food chain makes possible for the food to pass from the industrial producer, who has properly frozen it in every step of the way, to the consumer's table without ever defrosting. But in the real 
world, it may not be so easy to realize whether the food has been refrozen with the risk of bringing to the table a product that has been depleted even if it is apparently intact. With the blockchain, this risk does not exist because it would not be possible to resolve and approve an emissive transaction inconsistent with the previous steps.

At this stage, if a carbon border adjustment tax is to be introduced by the $\mathrm{EU}^{67}$ then, should be done in a way that this imposition creates competition based on real emissions. This also to monetize the efforts made in recent years to decarbonize the European industrial system. This way, adding "sustainability" as a parameter of competition at least in the EU market. ${ }^{68}$ It is worthy for the EU to introduce emissions standards that encourage foreign industrial competitors to embrace the climate change values that Europe has set itself. Probably those who believe that, with the introduction of the charge on added emissions, there could be an initial increase in costs for European producers who source raw materials and semi-finished products from outside Europe are probably not wrong. However, such criticisms, given a correct analysis, would lose sight of the structure of the mechanism, which intends to favour only sustainable productions to the detriment of the more emissive ones, and not the place of production. In practical terms, the European producer who source raw materials and semifinished products on the international market, with the charge on added emissions mechanism, would simply buy, those materials and semi-finished products, which he needs, from the most sustainable producer, whether it is European or non-EU.

\section{Conclusions}

In the last hundred years, issues on environmental protection have passed two macro-phases; the first ${ }^{69}$ led to the rise of a full awareness in the limitation of the planet's

\footnotetext{
${ }^{67}$ In this sense, cf. Article 30 "Review in the light of the implementation of the Paris Agreement and the development of carbon markets in other important economies" of Dir. 2018/410 /EU, where this idea is considered in paragraph 2. "The measures to support certain energy-intensive industries that may be subject to carbon leakage referred to in Articles 10a and 10b shall also be kept under review in the light of climate policy measures in other major economies. In this context, the Commission shall also consider whether measures in relation to the compensation of indirect costs should be further harmonized".

68 The impact of Charge on added emissions on the overall demand of goods imported into the EU will, of course vary according to the cost attributed to $\mathrm{CO}_{2}$. However, in my opinion, this interesting point should be addressed extensively in a specific paper.

${ }^{69}$ In which the Report on the limits of development (from the book The Limits to Growth. The limits of development), commissioned to MIT by the Club of Rome (1972), had a fundamental stage.
}

resources, with the approval of the United Nations Framework Convention on Climate Change in 1992 and the second is characterized by the attempt to create binding targets and limits on the exploitation of resources at international level. Never before there had been an attempt to find a shared solution at a global level to a recognized common problem. The EU chose to pursue with emissions binding targets even in the absence of similar obligations of the other industrialized countries. ${ }^{70}$ The EU considered that a "leading by example" approach would also have dragged others towards sustainability. The EU has continued along this path with great consistency but also by modifying the instruments deployed over time.

Developments in the European approach have been marked by increasing horizontal and vertical integration. The correlation between contiguous and interconnected sectors over the time has increased: a common objective of decarbonization even in presence of separately dealt issues. This process is ongoing. An interesting debate is taking place to ensure ecological and energy transition does not create a lack of competitiveness in European industry. The problem is that, difficulties of the energy transition are not exclusively linked to the so-called carbon leakage but they are structural and concern the fact that if European industries are aggravated by asymmetric costs in the European and global market, any percentage of the market that the EU loses will necessarily be in favour of the more polluting non-EU industries.

The ecological and energy transition must therefore take into account the carbon intensity of the European industrial plants and goods. From this assumption, comes the need to find and use new tools that adapt flexibly to the maintenance of European ${ }^{71}$ industrial competitiveness. Among

\footnotetext{
$\overline{70}$ Among the most important criticisms of the Kyoto Protocol was that which considered the anti-competitive nature of the measures. In other words, it was believed that the differences between the Annex I countries and the developing countries were not correct from an economic point of view and that the double track would have given countries not subject to emission restrictions an undue economic advantage. This was also the position of the US, which did not send the signed Kyoto Protocol to the US Senate. Objections, which, in retrospect, would have proved not entirely unjustified.

${ }^{71}$ The sectoral industrial perspective of reconciling climate and energy policies (own-initiative opinion) EESC 2019/927-CCMI/167 545th Plenary Session. July 2019 Rapporteur: Aurel Laurenţiu PLOSCEANU (GR.I-RO) Co-rapporteur: Enrico GIBELLIERI (Cat.2-IT) DG CLIMA-Commissioner responsible ARIAS CANETE states that “... In her Political Guidelines, Commission President-elect von der Leyen announced her intention to introduce a Carbon Border Tax to avoid carbon leakage, which should be fully compliant with World Trade Organization rules". See also my feedback to the Commission on the carbon border adjustment tax https://ec.europa.eu/info/law/better-regulation/have-your-say/initia tives/12228-EU-Green-Deal-carbon-border-adjustment-mechanism-/ F509815
} 
these, the proposal of a carbon tax at the border is one of the reforms closest to implementation.

However, integration also takes place vertically. If, for example, according to Directive 2003/87/EC implementing the Kyoto Protocol the cap and the emissions permit were issued at the State level, with Directive 2009/29/EU these became Union. Over the years, the Commission and the EU Parliament have consistently called for competence in energy and environmental matters. As mentioned above, the next step towards European integration will be through common taxation and this will take place, in the energy and environmental sectors, because other areas of taxation are likely to be more divisive. A first step in this direction was seen in the reset of the budgetary rules following the economic and pandemic crisis of COVID-19. ${ }^{72}$ A redistribution of the EU's own economic resources will set a significant precedent.

To create flexible instruments to protection environment and European industrial plants set in a globalized economic context, flexibility should not be an approximate tool that leaves a margin of opacity to the emissivity behaviour of the players, nor a linear instrument that equates industries summarily according to their origin to mere belonging to one or another category. For a flexible instrument to function is required a mechanism that in an elastic manner emphasise the sustainability of industries operating in the European market.

The fundamentals of the Charge on Emissions are as follows:

1. The accurate calculation of real emissions by-product

2. The traceability of emissions

3. Consumers environmental awareness raising through the indirect taxation and the fiscal neutrality

4. Compatibility with the WTO resulting from a nondiscriminatory approach.

This mechanism is not a linear tax applied at the border on the import from non-EU countries based on their average emissions, but instead it proposes to accurately account for greenhouse gas emissions regardless of where these goods were physically produced.

The specific calculation of emissions should avoid the environmental dumping phenomena, already evident in the fiscal sector and in the labour costs. It should discourage non-EU companies from misleadingly representing their products as manufactured in countries recognized by the European Union as low emitters.

The second point of the proposal consists in verifying and tracing emissions through a mechanism based on the accreditation of private companies by the EA-European co-operation for Accreditation capable of verifying

$\overline{72}$ See on this issue D'Adamo et al. (2020). emissions. This proposal addresses directly private EU and non-EU industries, on a voluntary basis, giving them the opportunity to obtain the certification, i.e. to show their real emissions. For companies that decide not to certify their emissions, the EU should assume that their emissions are the highest attributed to the production of that particular good and value them accordingly within the VAT.

The tracing of direct and indirect emissions through the entire production chain takes place in the Charge on Emissions with the use of blockchain technology, recognized as reliable and safe, which allows you to certify the amount of CO2eq emissions accumulated in each step of the production chain: therefore, tracking each "issuing transaction".

The EU should adopt an administered price per tonne of $\mathrm{CO}_{2}$ emitted, which should be valued in percentages and proportionally to the VAT applying to all products on the European market. This mechanism provides for a burden on the goods of the most polluting industries and a lowering of VAT on low emissions products up to the compensation of costs related to sustainability. According to me, the higher revenue deriving from the attribution of an increased VAT for the most emissive goods should allow a lowering of taxation on the more sustainable ones while maintaining a substantial "fiscal neutrality".

Finally, the emissions accuracy regarding the attribution to goods does not discriminate because this approach is not based on the origin of the products, making this way the place of production irrelevant. By directly penalizing the $\mathrm{CO}_{2}$ emitted during the production of goods, the Charge on Emission would integrate and would not violate art. 2, paragraph 2, lett. a) "the most favour nation" of the General Agreement on Customs Tariffs and Trade, one of the founding agreements of the World Trade Organization, the WTO.

The EU is working on a process that highlights the difference between the sustainability of industrial processes $^{73}$ and to make also it clear to consumers. With this view, EU should surpass the territorial approach adopted so far.

The charge on added emissions, explained and demonstrated in this paper, is a proposal that stands for over eight years in the Italian and European debate and that can help

\footnotetext{
${ }^{73}$ EU Commissioner for Economic Affairs Gentiloni, during an event organized by the French government on 23 March 2021 states that "to ensure that the price of imports more accurately reflects the quantity of emissions" will introduce a new tax that "will make the price of carbon equal of European and imported products "and may" incentivize foreign producers to invest in greener production processes and third countries to increase their climate ambition". See also my feedback to the Commission on the carbon border adjustment tax https://ec.europa.eu/info/law/better-regulation/haveyour-say/initiatives/12228-EU-Green-Deal-carbon-border-adjust ment-mechanism-/F509815.
} 
to clarify the dynamics of a new supra-territorial and punctual approach in the calculation of emissions. In fact, in 2017, the Charge on Emissions proposal was object of a resolution of the Italian Senate's Joint Commissions of Productive Activities and Environment approved at the conclusion of the examination of the deal assigned on competitive asymmetries for European industry deriving from the low energy costs and low environmental standards in non-EU Countries. In addition, the proposed mechanism is supported by ENEA. ${ }^{74}$ The Charge on Emissions mechanism is one of the three proposals that the European Economic and Social Committee suggested to the European Commission for further investigation in view of the current competitive asymmetry.

Funding I declare that this research received no fundings.

\section{Declarations}

Conflict of interest I declare I have no conflict of interest.

\section{References}

Ahmed, S., Taqi, H. M. M., Farabi, Y. I., et al. (2021). Evaluation of flexible strategies to manage the COVID-19 pandemic in the education sector. Global Journal of Flexible Systems Management. https://doi.org/10.1007/s40171-021-00267-9

Baker, Shultz, \& Paulson. (2017). A border adjustment tax in the new administration. International New York Times of 09/02/2017.

Baumol, W. J., \& Oates, W. E. (1971). The use of standards and prices for protection of the environment. In The economics of environment (pp. 53-65). Palgrave Macmillan.

Borghesi, S., Montini, M., \& Barreca, A. (2016). The European emission trading system and its followers: Comparative analysis and linking perspectives. Springer.

Brown, J. L. (2018). Environmental economics. The Editors of Encyclopadia Britannica 2018. https://www.britannica.com/ topic/environmental-economics. Accessed 30 June 302021 (2018).

Chuang, J., Lien, H. L., Roche, A., Liao, P. H., \& Den, W. (2019). Consolidated climate markets mechanism analysis. Case studies of China, Japan, and Taiwan. Sustainability, 11(22), 6478.

Clò, S. (2010). Grandfathering, auctioning and Carbon Leakage: Assessing the inconsistencies of the new ETS Directive. Energy Policy, 38(5), 2420-2430.

Clò, S. (2011). Emissions Trading Scheme (ETS) tra Mercato e Regolazione: funzionamento e risultati. "Emissions Trading Scheme (ETS) tra Mercato e Regolazione: funzionamento e risultati" presentazione al Ministeri dell'Economia e delle Finanze. Roma.

Club of Rome. (1972). The limits to growth. The limits of development), commissioned to MIT by the Club of Rome.

Communication from the Commission to the European Parliament, the European Council, the Council, the European Economic and Social Committee and the Committee of the Regions. A New Industrial Strategy for Europe, Brussels, 10.3.2020.

\footnotetext{
${ }_{74}$ Italian National Agency for New Technologies, Energy and Sustainable Economic Development.
}

Communication from the Commission to the European Parliament, the European Council, the Council, the European Economic and Social Committee and the Committee of the Regions. A New Industrial Strategy for Europe, Brussels, 10.3.2020 COM (2020) 102 final.

Courchene, T. J., \& Allan, J. R. (2008). Climate change: The case for a carbon tariff/tax. Policy Options-Montreal, 29(3), 59.

Court's judgment of 2 April 1998. Outokumpu Oy. Reference for a preliminary ruling: Uudenmaan lääninoikeus-Finland. Manufacturing tax on electricity-Tax rates differentiated according to the mode of production of electricity of national originSingle rate for imported electricity. Case C-213/96.

Cucchiella, F., D’Adamo, I., Gastaldi, Koh, S. C. L., Rosa. P. (2017). A comparison of environmental and energetic performance of European countries: A sustainability index. Renewable and Sustainable Energy Reviews, 78, 401-413. ISSN 1364-0321.

D’Adamo, I., Gastaldi, M., \& Morone, P. (2020). The post COVID-19 green recovery in practice: Assessing the profitability of a policy proposal on residential photovoltaic plants. Energy Policy, 147, 111910.

Decreto-legge del 30 agosto 1993 n. 331 on harmonization of provisions relating to taxes on mineral oils, alcohol, alcoholic beverages, manufactured tobacco and VAT with those laid down in EEC Directives and consequent amendments thereto, as well as provisions on the regulation of approved tax assistance centres, procedures for tax refunds, the exclusion from ILOR of entrepreneurial income up to the amount corresponding to the direct employment contribution, the introduction of an extraordinary tax on certain assets and other tax provisions for 1993.

Delbeke, J., \& Vis, P. (2020). Towards a climate-neutral Europe: Curbing the trend (p. 248).

Demailly, D., \& Quirion, P. (2008). European Emission Trading Scheme and competitiveness: A case study on the iron and steel industry. Energy Economics, 30(4), 2009-2027.

Directorate-General for Climate Action. (2015). Study on the impacts on low carbon actions and investments of the installations falling under the EU Emissions Trading System (EU ETS), cit. pg. 179.

Egenhofer, C. (2007). The making of the eu emissions trading scheme: Status, prospects and implications for business. European Management Journal, 25(6), 453-463.

Ellerman, A. D., \& Buchner, B. K. (2007). The European Union emissions trading scheme: Origins, allocation, and early results. Review of Environmental Economics and Policy, 1(1), 66-87.

European Commission. (2003). Staff working document impact assessment accompanying document to the Commission Decision determining a list of sectors and subsectors which are deemed to be exposed to a significant risk of carbon leakage pursuant to Article 10a (13) of Directive 2003/87/EC (2009)10251 final.

European Commission. (2011). Decision 2011/278/EU as adopted on 27 April 2011, the Commission shall determine the annual reduction rate for each benchmark, and shall apply it to the benchmark values applicable in the period from 2013 to 2020 in respect of each year between 2008 and 2023 to determine the benchmark values for the period from 2021 to 2025 .

European Commission. (2019). Commissione europea, Relazione della Commissione al Parlamento Europeo e al Consiglio sul funzionamento del mercato europeo del carbonio. COM/2019/ $557 \mathrm{final} / 2$.

European Commission. (2020). On behalf of the European Union and its Member States Zagreb, 6 March 2020 Subject: Long-term low GHG development strategy of the European Union and its Member States. https://unfccc.int/sites/default/files/resource/HR03-06-2020\%20EU\%20Submission\%20on\%20Long\%20term\% 20strategy.pdf 
European Court's judgment of 2 April 1998. Outokumpu Oy. Reference for a preliminary ruling: Uudenmaan lääninoikeusFinland. Manufacturing tax on electricity-Tax rates differentiated according to the mode of production of electricity of national origin-Single rate for imported electricity. Case C-213/96.

European Economic and Social Committee. (2019). Opinion of the European Economic and Social Committee on 'The sectoral industrial perspective on reconciling climate and energy policies' (own-initiative opinion) (2019/C 353/10). Official Journal of the European Union, 18.10.2019.

European Union. (2003). Directive 2003/87/EC of the European Parliament and of the Council of 13 October 2003 establishing a scheme for greenhouse gas emission allowance trading within the Community and amending Council Directive 96/61/EC.

European Union. (2009a). Staff working document impact assessment Brussels, 24.12.2009 SEC (2009) 1710 final draft accompanying document to the Commission Decision determining a list of sectors and subsectors which are deemed to be exposed to a significant risk of carbon leakage pursuant to Article 10a (13) of Directive 2003/87/EC (2009)10251 final.

European Union. (2009b). Directive 2009/29/EC of the European Parliament and of the Council of 23 April 2009 amending Directive 2003/87/EC so as to improve and extend the greenhouse gas emission allowance trading scheme of the Community.

European Union. (2014). DG Trade, Report on Energy and competitiveness 2014

European Union. (2015). Decision (EU) 2015/1814 of the European Parliament and of the Council of 6 October 2015 concerning the establishment and operation of a market stability reserve for the union greenhouse gas emission trading scheme and amending directive 2003/87/EC

European Union. (2018). Directive (EU) 2018/410 of the European Parliament and of the Council of 14 March 2018 amending Directive 2003/87/EC to enhance cost-effective emission reductions and low-carbon investments, and Decision (EU) 2015/1814

European Union. (2019). Communication from the Commission to the European Parliament, the European Council, the Council, the European Economic and Social Committee and the Committee of the Regions. The European Green Deal. Brussels, 11.12.2019. COM (2019) 640 final.

European Union. (2021). The EU's 2021-2027 long-term budget \& NextGenerationEU Facts and figures. Published: 2021-04-29 by Directorate-General for Budget (European Commission).

Evans, S., \& Bahrami, H. (2020). Super-flexibility in practice: Insights from a crisis. Global Journal of Flexible Systems Management, 21(3), 207-214.

Fabbri, F. (2017). EU 2030 Climate energy policy. In 2nd AIEE Energy Symposium Conference Proceedings (pp. 228-235). AIEE - The Italian Association of Energy Economists.

Favaro, T. (2019). Blockchain technologies for electricity trading regulation. In 4th AIEE Energy Symposium. Current and future challenges to energy security (pp. 223-233). AIEE - The Italian Association of Energy Economists.

Fu, B., Shu, Z., \& Liu, X. (2018). Blockchain enhanced emission trading framework in fashion apparel manufacturing industry. Sustainability, 10(4), 1105.

Gerbeti, A. (2010). La nuova direttiva europea sullo scambio delle quote di emissione: luci ed ombre. Rivista Giuridica Dell'ambiente, 1, 183-189.

Gerbeti, A. (2014). CO2 nei beni e competitività industriale europea. Editoriale Delfino. ISBN: 978-88-97323-33-4.
Gerbeti, A. (2016). CO2 in goods. In Green fiscal reform for a sustainable future: Reform, innovation and renewable (pp. 77-92). Edward Elgar Publishing.

Gerbeti, A (2019). I limiti geografici del capitalismo. QualEnergia novembre/dicembre 2019 Anno XVII. n.5.

Gerbeti, A. (2020). Feedback to the Commission on the carbon border adjustment tax. https://ec.europa.eu/info/law/better-regu lation/have-your-say/initiatives/12228-EU-Green-Deal-carbonborder-adjustment-mechanism-/F509815

Gerbeti, A., \& Catino, F. (2019). Blockchain e tracciabilità delle emissioni industriali. Energia, 2, 56-61.

German Environment Agency, EU ETS up to 2030: Adjusting the Cap in light of the IPCC $1.5^{\circ} \mathrm{C}$ Special Report and the Paris Agreement, 07/2020.

Gilbertson, T., \& Reyes, O. (2009). Carbon trading. How it works and why it fails. Critical Currents, (7).

Gloaguen, O., \& Alberola, E. (2013). Assessing the factors behind $\mathrm{CO} 2$ emissions changes over the phases 1 and 2 of the EU ETS: an econometric analysis. CDC climate research working paper no, 2013-15.

Grubb, M., \& Neuhoff, K. (2006). Allocation and competitiveness in the EU emissions trading scheme: Policy overview. Climate Policy, 6(1), 7-30. Cit. pp 35, 38.

Hanoi General Office of Statistics. (2020). Hanoitimes-Economic and urban newspaper, Anh Hong "Vietnam remains promising destination for foreign investors", Jan 02, 2020.

Hillman, A. L. (2013). The political economy of protection. Taylor \& Francis.

IEA, International Energy Agency. (2019). Global Energy and CO2 Status Report 2018, Paris.

Intergovernmental Panel on Climate Change. (2007). Climate change 2007: Mitigation; Contribution of Working Group III to the Fourth Assessment Report.

Joltreau \& Sommerfeld. (2019). Why does emissions trading under the EU Emissions Trading System (ETS) not affect firms' competitiveness? Empirical Findings from the Literature, Climate Policy, 19(4), 453-471. https://doi.org/10.1080/14693062. 2018.1502145

Khaqqi, K. N., Sikorski, J. J., Hadinoto, K., \& Kraft, M. (2018). Incorporating seller/buyer reputation-based system in blockchain-enabled emission trading application. Applied Energy, 209, 8-19.

MacDonald, L., \& Cao, J. (2014). The sudden rise of carbon taxes, 2010-2030.

Mauro, B. (2019). Blockchain: Cos'è, come funziona e gli ambiti applicativi in Italia. https://www.blockchain4innovation.it/ esperti/blockchain-perche-e-cosi-importante/

McLure, C. E., Jr. (2010). The carbon-added tax: An idea whose time should never come. Carbon \& Climate Law Review, 4, 250.

Ministère de l'écologie, de l'énergie, du développement durable et de l'aménagement du territoire, France. Preventing carbon leakage through a border adjustment mechanism Bruxelles-le 11 avril 2008 .

Monjon, S., \& Quirion, P. (2011). Addressing leakage in the EU ETS: Border adjustment or output-based allocation? Ecological Economics, 70(11), 1957-1971.

Naegele, H., \& Zaklan, A. (2019). Does the EU ETS cause carbon leakage in European manufacturing? Journal of Environmental Economics and Management, 93, 125-147.

OECD. (2010). Measuring globalisation: OECD economic globalisation indicators. OECD.

Picek, O. (2020). Spillover effects from next generation EU. Intereconomics, 55, 325-331. https://doi.org/10.1007/s10272020-0923-z

Regolamento (Ue) N. 176/2014 della Commissione del 25 febbraio 2014 recante modifica del regolamento (UE) n. 1031/2010 al fine 
di determinare, in particolare, i volumi delle quote di emissioni dei gas a effetto serra da mettere all'asta nel periodo 2013-2020.

Resolution of the joined Commissions X and XIII, approved at the conclusion of the examination of the deal assigned on competitive asymmetries for European industry deriving from the low energy costs and low environmental standards in non-EU Countries, 1st August 2017. Doc. XXIV, n. 79 of the Italian Senate's Joint Commissions Productive Activities and Environment.

Rui Shan Oak Ridge National Laboratory, USA; Yaojin Sun, University of Tennessee, USA; and Sylvain Audette, HEC Montréal, Canada. Bitcoin mining to reduce the renewable curtailment: a case study of CAISO. In 4th AIEE Energy Symposium. Current and future challenges to energy security. Conference Proceedings. 10-12 December, in Rome, Italy. Published 2019 by: The Italian Association of Energy Economists (AIEE), Rome, Italy, p. 61.

Santibanez-Gonzalez, E. D. R. (2017). Installations for the capture of $\mathrm{CO} 2$, to pipelines for transport of $\mathrm{CO} 2$ or to $\mathrm{CO} 2$ storage sites, where he explores the relationship between establishing a pricing policy (tax) on carbon dioxide emissions to the atmosphere and the design of a supply chain network to capture and sequester carbon dioxide in geological reservoirs.

Santibanez-Gonzalez, E. D. (2017b). A modelling approach that combines pricing policies with a carbon capture and storage supply chain network. Journal of Cleaner Production, 167, $1354-1369$.

Scalia F. (2020). Energia sostenibile e cambiamento climatico. Profili giuridici della transizione (pp. 518-534). Giappichelli 01/2020, Milano.

Shukla, S. K., Sushil, \& Sharma, M. K. (2019). Managerial paradox toward flexibility: Emergent views using thematic analysis of literature. Global Journal of Flexible Systems Management, 20(4), 349-370. https://doi.org/10.1007/s40171-019-00220-x

Sijm, J., Neuhoff, K., \& Chen, Y. (2006). CO2 cost pass-through and windfall profits in the power sector. Climate Policy, 6(1), 49-72.

Sushil, S. (2011). Flexibility, vitality and sustainability. Global Journal of Flexible Systems Management, 12(1-2), iii.

Sushil, S. (2015). Valuation of flexibility. Global Journal of Flexible Systems Management, 16(3), 219-220. https://doi.org/10.1007/ s40171-015-0100-6

The General Agreement on Tariffs and Trade (GATT 1947).
Tientenberg, T. (2010). Cap and trade: The evolution of an economic idea. Agricultural and Resource Economics Review, 39(3), 359-367.

Treccani, Volume III. Nuovi Sviluppi: Energia, Trasporti, Sostenibilità, cap. 7. Confronto tra sistemi energetici. http://www. treccani.it/export/sites/default/Portale/sito/altre_aree/Tecnolo gia_e_Scienze_applicate/enciclopedia/italiano_vol_2/631-650_ ita.pdf

United Nations Environment Programme and the World Trade Organization. (2009). Trade and climate change. Cit. pg. 21.

Wojciech, M. (2019). The delocalisation of production to Poland. Production Engineering Archives, 23, 47-52.

\section{Key Questions}

1. In a globalized economy, does it make sense to attribute obligations to the industries based on territoriality rather than on product's standard (released emissions, energy efficiency etc.)?

2. Costs of European decarbonization are paid directly or indirectly by citizens. Would be more effective having more transparency of these costs so that consumers could choose the low emissive products?

Publisher's Note Springer Nature remains neutral with regard to jurisdictional claims in published maps and institutional affiliations.

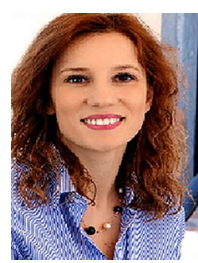

Agime Gerbeti Adjunct professor on Environmental law. She is a member of the IT G20 Environmental Team of the G20 Italian Presidency. She works for GSE and before for the Ministry of Environment. The "Charge on emissions" proposal, contained in her book "CO2 in goods and European industrial competitiveness", is among the mechanisms assessed at European level for an environmental tax reform. She wrote books, several articles and for the Italian Encyclopaedia Treccani on environment and energy issues. 